\title{
Evaluation of Resistance to Powdery Mildew in Triticale Seedlings and Adult Plants
}

V. Troch, K. Audenaert, and A. Vanheule, Faculty of Applied Bioscience Engineering, University College Ghent (Ghent University Association), and Department of Crop Protection, Laboratory of Phytopathology, Ghent University; B. Bekaert, Faculty of Applied Bioscience Engineering, University College Ghent (Ghent University Association); M. Höfte, Department of Crop Protection, Laboratory of Phytopathology; and G. Haesaert, Faculty of Applied Bioscience Engineering, University College Ghent (Ghent University Association), and Department of Crop Protection, Laboratory of Phytopathology, Ghent University, BE-9000 Ghent, Belgium

\begin{abstract}
Troch, V., Audenaert, K., Vanheule, A., Bekaert, B., Höfte, M., and Haesaert, G. 2013. Evaluation of resistance to powdery mildew in triticale seedlings and adult plants. Plant Dis. 97:410-417.

Triticale $(x$ Triticosecale) is the intergeneric hybrid between the female parent wheat and the male parent rye. With the expansion of the triticale growing area, powdery mildew emerged on this new host and has become a significant disease on triticale. Recent research demonstrated that this "new" powdery mildew on triticale has emerged through a host range expansion of powdery mildew of wheat. Moreover, this expansion occurred recently and multiple times at different locations in Europe. An effective and environmentally sensitive approach to controlling powdery mildew involves breeding crop plants for resistance. The main goal of this study was to identify the presence of powdery mildew resistance in commercial triticale cultivars. First, the avirulence $(A V R)$ genes and gene complexity carried by this new powdery mildew population on triticale were characterized. Virulence was identified for all the resistance genes evaluated in the present study, and virulence

Pm6, Pm7, Pm8, and Pm17. Using molecular markers, the presence of resistance genes $P m 3 f$ and $P m 17$ was identified in certain triticale cultivars. The triticale cultivars were also evaluated for the presence of quantitative resistance at adult plant growth stages in a 2-year field experiment. Despite the high disease pressure, cultivars highly resistant at the adult-plant growth stages were identified. Because 'Grenado' also showed effective race-specific resistance, this cultivar could be of high value for breeding for durable resistance to powdery mildew. Altogether, this study reveals valuable information on the presence of powdery mildew resistance in commercial triticale cultivars, which can be used in breeding programs in triticale. Additionally, this study underscores the need to broaden the base of powdery mildew resistance in triticale through introgression and deployment of new sources of mildew resistance, including quantitative resistance.
\end{abstract} frequencies higher than 50\% were recorded on the genes Pm3f, Pm5b,
Triticale ( $\times$ Triticosecale Wittmack) is the intergeneric hybrid between the female parent wheat (Triticum ssp.) and the male parent rye (Secale spp.). This artificial cereal combines the rye characteristics of cold, disease tolerance, and adaptation to unfavorable soils and climates with the productivity and nutritional qualities of wheat (49). Therefore, triticale is widely grown in areas that are not suitable for wheat production due to abiotic stress conditions (40). Such conditions prevail in many parts of the world, and are still increasing (35). Triticale is commonly used as fodder for livestock (40) and, traditionally, has required little or no fungicide treatments.

Triticale was first commercialized at the end of the 1960s $(1,35)$ and, since then, many new genotypes have been released. At present, France, Germany, and Poland are the most important countries for triticale breeding and production in Europe (35). During the last decade, triticale has gained considerable importance in Europe, because its production area has nearly doubled since 2000 (up to almost 3.3 million ha in 2010) (13). However, with the expansion of the triticale growing area, powdery mildew has emerged and become a significant disease on this new host. This has been simultaneously observed in several European countries $(48,49)$.

Powdery mildew, caused by Blumeria graminis, is a major problem in cereal production, because it can reduce quality and yield $(8,12)$. B. graminis is an obligate biotrophic fungus, depending on

Corresponding author: V. Troch, E-mail: Veronique.troch@hogent.be

Accepted for publication 12 October 2012.

http://dx.doi.org/10.1094/PDIS-02-12-0161-RE

(C) 2013 The American Phytopathological Society living plant cells for survival and reproduction. In this way, $B$. graminis has evolved eight distinct formae speciales, each adapted to a specific host $(26,36)$. Recent research demonstrated that this "new" powdery mildew on triticale has emerged through a host range expansion of powdery mildew of wheat (49). Moreover, this expansion occurred recently and multiple times at different locations in Europe (48).

An effective and environmentally sensitive approach to disease control involves breeding crop plants for resistance (11). Two general categories of host resistance have long been recognized in plants: qualitative resistance conferred by a single resistance $(R)$ gene and quantitative resistance mediated by multiple genes, with each providing a partial increase in resistance $(22,39)$. However, it is important to note that host resistance often cannot be described simply as either qualitative or quantitative and, in some cases, a gray zone between the two may exist $(39,44)$.

In qualitative resistance, known as gene-for-gene resistance (14) or effector-triggered immunity (ETI) (19), the outcome of infection is based on the interaction of dominant $(R)$ genes in the host and dominant avirulence $(A V R)$ genes in the pathogen. To date, over 58 powdery mildew $R$ genes and alleles ( $P m$ genes), mapped to 43 loci, have been characterized in wheat, and new ones are regularly described $(9,41)$. However, no information is available with respect to the presence of race-specific powdery mildew $R$ genes in current commercial triticale cultivars, because until recently this was not an important selection criterion in triticale breeding (49). Moreover, in the context of host range expansion, a few modifications in the effector repertoire of $B$. graminis f. sp. tritici were probably sufficient to adapt to closely related triticales (48). Knowledge of the identity of race-specific $R$ genes or alleles in commercial triticale cultivars, and of the spectrum of avirulence/virulence in the recently emerged powdery mildew populations, is a requirement to identify which resistance breakdown occurred. 
Gene postulation is the most frequent method to determine the presence of probable race-specific powdery mildew seedling $R$ genes. In this method, infection types observed on host lines carrying known genes for resistance are compared with those of the lines in question after infection by a range of pathogen isolates with different $A V R$ genes. Many researchers have used this method for identifying powdery mildew $R$ genes $(\mathrm{Pm})$ in wheat genotypes $(17,24,43,50)$.

The use of molecular markers is a genetic approach to identify $R$ genes. In wheat, only the $P m 3 b$ powdery mildew $R$ gene has been cloned thus far (52). This gene is a member of the coiled-coil nucleotide-binding site leucine-rich repeat (NBS-LRR) class of disease $R$ genes (5). Availability of this gene sequence has facilitated the development of specific primers for each of the seven distinct alleles (Pm3a to $-g$ ) (47). Polymerase chain reaction (PCR)-based markers are also available for the wheat-rye translocations involving 1AL.1RS and 1BL.1RS (20,31), carrying $R$ genes $P m 17$ and $P m 8$, respectively. Moreover, Walker et al. (49) found some indications for the presence of $P m 8$ in triticale by pathotype testing.

Pathogens may evolve to overcome race-specific host resistance by altering their $A V R$ genes to avoid $R$-dependent recognition (19). A more sustainable alternative to race-specific $R$ genes is quantitative resistance, also called partial or adult plant resistance (44). This resistance, controlled by multiple genes, each with smaller effects, is expressed as a reduction in disease rather than as the absence of disease (39).

The first objective of the present study was to characterize the $A V R$ genes and gene complexity carried by the powdery mildew population collected from triticale. In addition, the $A V R$ genes carried by the powdery mildew population collected from wheat were determined for comparison. Information on the frequency of $A V R$ genes in the triticale powdery mildew population can provide insights into the corresponding $R$ genes present in commercially grown triticale cultivars, including an indication of genes that lost their effectiveness. Additionally, the second objective was to identify $\mathrm{Pm}$ genes that condition powdery mildew resistance in commercial triticale cultivars, using gene postulation and molecular markers. Finally, the third objective was to evaluate commercial triticale cultivars for adult plant resistance in the field.

\section{Materials and Methods}

Fungal material. Leaves infected with powdery mildew were sampled before the peak incidence of powdery mildew development in commercially grown crops of triticale and wheat during 2009 and 2010. Single-colony isolates were derived from the infected leaves according to Imani et al. (18). Isolates were cultured on detached leaves on water agar $\left(5 \mathrm{~g} \mathrm{liter}^{-1}\right)$ amended with benzimidazole (40 mg liter ${ }^{-1}$ ) in petri dishes (7). Cultures were main-

Table 1. Wheat differential lines with single genes for resistance used to determine the virulence genes in powdery mildew isolates (adapted from Hsam and Zeller [16])

\begin{tabular}{llll}
\hline Cultivar & $\begin{array}{c}\text { Gene or } \\
\text { allele }\end{array}$ & \multicolumn{1}{c}{ Location } & \multicolumn{1}{c}{ Source } \\
\hline Axminster & $P m 1 a$ & 7AL & Triticum aestivum \\
Galahad & $P m 2$ & 5DS & Aegilops tauschii \\
Asosan & $P m 3 a$ & 1AS & T. aestivum \\
Chul & $P m 3 b$ & 1AS & T. aestivum \\
Sonora & $P m 3 c$ & 1AS & T. aestivum \\
Broom & $P m 3 d$ & 1AS & T. aestivum \\
Michigan Amber & $P m 3 f$ & 1AS & T. aestivum \\
Khapli & $P m 4 a$ & 2AL & T. dicoccum \\
Weihenstephan M1 & $P m 4 b$ & 2AL & T. carthlicum \\
Hope & $P m 5 a$ & $7 \mathrm{BL}$ & T. dicoccum \\
Ibis & $P m 5 b$ & 7BL & T. aestivum \\
Holger & $P m 6$ & 2B & T. timopheevii \\
Transec & $P m 7$ & 4BS.4BL-2RL & Secale cereale \\
Kavkaz & $P m 8$ & 1BL.1RS & S. cereale \\
Amigo & $P m 17$ & 1AL.1RS & S. cereal \\
\hline
\end{tabular}

tained at $18^{\circ} \mathrm{C}$ with a 16 -h photoperiod and transferred to new leaves every 14 days. In total, 35 isolates were obtained from triticale at different fields in Belgium, France, and Poland. Twenty isolates obtained from wheat were also included in this study, sampled at different fields in Belgium. For the maintenance of the isolates collected from triticale and wheat, the susceptible host cultivars 'Lamberto' and 'Cerco', respectively, were used.

Plant material. The virulence of each isolate was assessed on a set of 15 wheat differential lines (Table 1) with known powdery mildew $R$ genes $(\mathrm{Pm})$ in order to determine the virulence genes associated with each isolate. These differential lines, kindly provided by James Brown from the John Innes Centre, cover the most common $R$ genes used in European wheat breeding (16). Fifteen commercial triticale cultivars from different European breeding companies were evaluated in this study for potential race-specific and partial resistance against powdery mildew (Table 2).

Seedling inoculation tests. Inoculation was performed by uniformly dispersing conidia in a settling tower measuring $300 \mathrm{~mm}$ high and $103 \mathrm{~mm}$ in diameter (7). Inoculation was carried out on 2week-old seedlings. For each isolate-cultivar combination, a petri dish containing three leaf segments of the cultivar and one leaf segment of a susceptible control was placed at the bottom of the tower, and conidia of the isolate were blown into the upper hole of the tower. Two independent inoculations were done for each isolate-cultivar combination. Inoculum density was approximately 20 conidia $\mathrm{mm}^{-2}$. Cultures were maintained on the same medium and under the same conditions as mentioned above. Infection types were scored 12 days after inoculation using a modified 0 -to-4 scale $(32,50)$. Plants showing infection type 0 to 1 were classified as resistant, infection type 2 as intermediate, and infection type 3 to 4 as susceptible. If infection types between replications were inconsistent, additional tests were carried out until a firm conclusion could be reached. For each cultivar, virulence frequencies were determined based on the proportion of isolates inducing an intermediate to susceptible reaction. Virulence complexity data (i.e., the number of differential lines on which an isolate was virulent) were analyzed with a nonparametric Kruskal-Wallis test (SAS Inc.)

Postulation of Pm genes. Postulation of $R$ genes was based on the gene-for-gene relationship (14). First, a standard set of isolates collected from triticale with different virulence profiles on the differential wheat lines was selected and used for gene postulation in the triticale cultivars. This standard set of isolates consisted of six Belgian isolates, three French isolates, and six Polish isolates displaying complementary virulences (Table 3). Second, the resistance in each triticale cultivar was postulated in two steps by comparing the infection types with the previously determined infection types on the wheat differential lines with known Pm genes, according to Lillemo et al. (24).

PCR detection of $\boldsymbol{P m}$ genes. Leaf tissue from 2-week-old seedlings, 8 to 10 individual plants per genotype, was bulked and ge-

Table 2. Commercial triticale cultivars, their breeding company, and country of origin evaluated for the presence of race-specific and partial resistance to powdery mildew

\begin{tabular}{lll}
\hline Cultivar & \multicolumn{1}{c}{ Breeding company } & Country \\
\hline Lamberto & DANKO & Poland \\
Krakowiak & DANKO & Poland \\
Moderato & DANKO & Poland \\
Grenado & DANKO & Poland \\
Maximal & Agri-Obtentions & France \\
Grandval & Agri-Obtentions & France \\
Borodine & Serasem & France \\
Ragtac & RAGT & France \\
Joyce & Sem-Partners & France \\
Tribeca & Fl. Desprez & France \\
Talentro & SW Seed & Sweden \\
Cultivo & SW Seed & Sweden \\
Agostino & SW Seed & Sweden \\
Partout & Saatzucht Dr. Hege GbR & Germany \\
Amarillo & Saatzucht Dr. Hege GbR & Germany \\
\hline
\end{tabular}


nomic DNA was extracted using the DNeasy Plant Mini Kit following the manufacturer's instructions (Qiagen). The presence of the 1RS translocation was tested by PCR amplification of the spacer region of the NOR-Rl gene on rye chromosome arm 1RS $(20,51)$. To distinguish the 1BL.1RS translocation from 1AL.1RS, the IAG95 marker was used according to Mohler et al. (31). As positive controls, 'Kavkaz' carrying Pm8 (1BL.1RS translocation) and 'Amigo' carrying Pm17 (1AL.1RS translocation) were used (Table 1). The presence of Pm3 alleles was tested using allele-specific primers, as described by Tommasini et al. (47). The following wheat lines were used as positive controls for the detection of the respective alleles: 'Asosan' for $P m 3 a$, 'Chul' for Pm3b, 'Sonora' for $P m 3 c$, 'Broom' for $P m 3 d$, and 'Michigan Amber' for Pm3f. DNA from Cerco, which carries no known powdery mildew $R$ genes, was used as a negative control in all tests.

Field evaluation. In parallel with the seedling experiments, the triticale cultivars listed in Table 2 were evaluated for partial resistance in a 2-year field experiment, conducted during the 200910 and 2010-11 growing seasons in Flanders. Field trials were conducted with a randomized complete block design with four replications. Each plot consisted of five 3-m rows spaced $25 \mathrm{~cm}$ apart. Approximately $75 \mathrm{~g}$ of seed were sown in each plot. Spreader rows of susceptible Lamberto surrounded the test cultivars to increase natural powdery mildew infection but no artificial inoculation was made.

Disease severity was scored four times between growth stage (GS)39 and GS73 (54) at intervals of 1 week. Ten leading tillers

Table 3. Infection types of a standard set of powdery mildew isolates collected from triticale on wheat differential lines ${ }^{\mathrm{a}}$

\begin{tabular}{|c|c|c|c|c|c|c|c|c|c|c|c|c|c|c|c|c|}
\hline \multirow[b]{2}{*}{ Wheat } & \multirow[b]{2}{*}{ Gene } & \multicolumn{15}{|c|}{ Standard set of isolates collected from triticale ${ }^{b}$} \\
\hline & & A27 & $\mathbf{A 3 7}$ & C6 & C10 & C3 & B14 & B8 & A28 & C9 & B9 & A21 & A24 & $\mathbf{C 2}$ & C8 & A22 \\
\hline Cerco & - & $\mathrm{S}$ & I & I & $\mathrm{S}$ & $\mathrm{S}$ & S & $\mathrm{S}$ & $\mathrm{S}$ & S & I & $\mathrm{S}$ & $\mathrm{S}$ & I & $\mathrm{S}$ & I \\
\hline Axminster & Pmla & $\mathrm{S}$ & $\mathrm{R}$ & $\mathrm{R}$ & $\mathrm{R}$ & $\mathrm{R}$ & I & $\mathrm{R}$ & I & I & $\mathrm{R}$ & $\mathrm{R}$ & $\mathrm{R}$ & I & $\mathrm{R}$ & $\mathrm{R}$ \\
\hline Galahad & $P m 2$ & $\mathrm{~S}$ & $\mathrm{~S}$ & $\mathrm{R}$ & $\mathrm{R}$ & $\mathrm{S}$ & $S$ & $\mathrm{~S}$ & I & $\mathrm{S}$ & I & $\mathrm{S}$ & I & $\mathrm{R}$ & $\mathrm{R}$ & $\mathrm{R}$ \\
\hline Asosan & $P m 3 a$ & $\mathrm{~S}$ & I & $\mathrm{S}$ & $\mathrm{R}$ & $\mathrm{R}$ & $\mathrm{S}$ & $\mathrm{R}$ & $\mathrm{R}$ & $\mathrm{S}$ & $\mathrm{R}$ & $\mathrm{R}$ & $\mathrm{R}$ & $\mathrm{R}$ & $\mathrm{R}$ & $\mathrm{R}$ \\
\hline Chul & $P m 3 b$ & $\mathrm{R}$ & $\mathrm{R}$ & $\mathrm{R}$ & $\mathrm{I}$ & $\mathrm{R}$ & $\mathrm{R}$ & $\mathrm{R}$ & $\mathrm{R}$ & $\mathrm{R}$ & $\mathrm{R}$ & $\mathrm{R}$ & $\mathrm{R}$ & $\mathrm{R}$ & $\mathrm{R}$ & $\mathrm{R}$ \\
\hline Sonora & $P m 3 c$ & $\mathrm{~S}$ & $\mathrm{R}$ & $\mathrm{R}$ & $\mathrm{S}$ & $\mathrm{S}$ & $\mathrm{R}$ & $\mathrm{S}$ & $\mathrm{R}$ & $\mathrm{S}$ & $\mathrm{S}$ & $\mathrm{R}$ & $\mathrm{R}$ & $\mathrm{R}$ & $\mathrm{R}$ & $\mathrm{R}$ \\
\hline Broom & $P m 3 d$ & $\mathrm{R}$ & $\mathrm{R}$ & $\mathrm{R}$ & $\mathrm{R}$ & $\mathrm{R}$ & $\mathrm{S}$ & $\mathrm{R}$ & $\mathrm{R}$ & $\mathrm{R}$ & $\mathrm{R}$ & $\mathrm{R}$ & $\mathrm{R}$ & $\mathrm{R}$ & $\mathrm{R}$ & $\mathrm{R}$ \\
\hline Michigan Amber & $P m 3 f$ & $\mathrm{I}$ & $\mathrm{R}$ & $\mathrm{S}$ & $\mathrm{S}$ & $\mathrm{S}$ & $\mathrm{S}$ & $\mathrm{S}$ & $\mathrm{S}$ & $\mathrm{S}$ & $\mathrm{R}$ & $\mathrm{S}$ & $\mathrm{R}$ & $\mathrm{R}$ & $\mathrm{R}$ & I \\
\hline Khapli & $P m 4 a$ & $\mathrm{R}$ & $\mathrm{R}$ & $\mathrm{R}$ & $\mathrm{R}$ & $\mathrm{R}$ & $\mathrm{R}$ & $\mathrm{R}$ & $\mathrm{R}$ & $\mathrm{S}$ & $\mathrm{R}$ & $\mathrm{R}$ & $\mathrm{R}$ & $\mathrm{R}$ & $\mathrm{R}$ & $\mathrm{R}$ \\
\hline Weihenste & $P m 4 b$ & $\mathrm{R}$ & $\mathrm{R}$ & $\mathrm{R}$ & $\mathrm{R}$ & $\mathrm{R}$ & $\mathrm{R}$ & $\mathrm{S}$ & $\mathrm{R}$ & $\mathrm{R}$ & $\mathrm{R}$ & $\mathrm{R}$ & $\mathrm{R}$ & $\mathrm{R}$ & $\mathrm{R}$ & $\mathrm{R}$ \\
\hline Hope & $P m 5 a$ & $\mathrm{I}$ & $\mathrm{R}$ & $\mathrm{R}$ & $\mathrm{R}$ & $\mathrm{R}$ & $\mathrm{R}$ & $\mathrm{R}$ & $\mathrm{R}$ & $\mathrm{R}$ & $\mathrm{S}$ & $\mathrm{R}$ & $\mathrm{R}$ & $\mathrm{R}$ & $\mathrm{R}$ & $\mathrm{R}$ \\
\hline Ibis & $P m 5 b$ & $\mathrm{~S}$ & $\mathrm{R}$ & $\mathrm{R}$ & $\mathrm{R}$ & $\mathrm{R}$ & I & $\mathrm{R}$ & $\mathrm{I}$ & $\mathrm{S}$ & $\mathrm{R}$ & $\mathrm{S}$ & $\mathrm{R}$ & $\mathrm{R}$ & $\mathrm{S}$ & $\mathrm{R}$ \\
\hline Holger & Pm6 & $\mathrm{S}$ & $\mathrm{R}$ & $\mathrm{S}$ & $\mathrm{S}$ & $\mathrm{R}$ & $\mathrm{S}$ & $\mathrm{R}$ & $\mathrm{S}$ & $\mathrm{S}$ & $\mathrm{S}$ & I & $\mathrm{S}$ & I & $\mathrm{R}$ & $\mathrm{R}$ \\
\hline Transec & $P m 7$ & $\mathrm{~S}$ & $\mathrm{R}$ & $\mathrm{R}$ & I & $\mathrm{R}$ & $\mathrm{R}$ & $\mathrm{R}$ & $\mathrm{R}$ & $\mathrm{S}$ & $\mathrm{R}$ & $\mathrm{S}$ & $\mathrm{S}$ & $\mathrm{S}$ & $\mathrm{S}$ & $\mathrm{R}$ \\
\hline Kavkaz & Pm8 & $\mathrm{S}$ & $\mathrm{S}$ & $\mathrm{S}$ & I & $\mathrm{S}$ & I & $\mathrm{S}$ & $\mathrm{S}$ & $\mathrm{S}$ & $\mathrm{S}$ & $\mathrm{S}$ & $\mathrm{S}$ & $\mathrm{S}$ & $\mathrm{S}$ & $\mathrm{R}$ \\
\hline Amigo & Pm17 & $\mathrm{S}$ & $\mathrm{R}$ & I & $\mathrm{R}$ & $\mathrm{S}$ & S & $\mathrm{R}$ & $\mathrm{R}$ & I & $\mathrm{R}$ & $\mathrm{R}$ & $\mathrm{R}$ & $\mathrm{R}$ & $\mathrm{S}$ & $S$ \\
\hline
\end{tabular}

a Triticale isolates were tested on wheat differential lines with known powdery mildew resistance genes $(P m)$. This set of isolates was used to postulate resistance genes on commercial triticale cultivars.

${ }^{\mathrm{b}} \mathrm{R}$, resistant; I, intermediate; $\mathrm{S}$, susceptible.

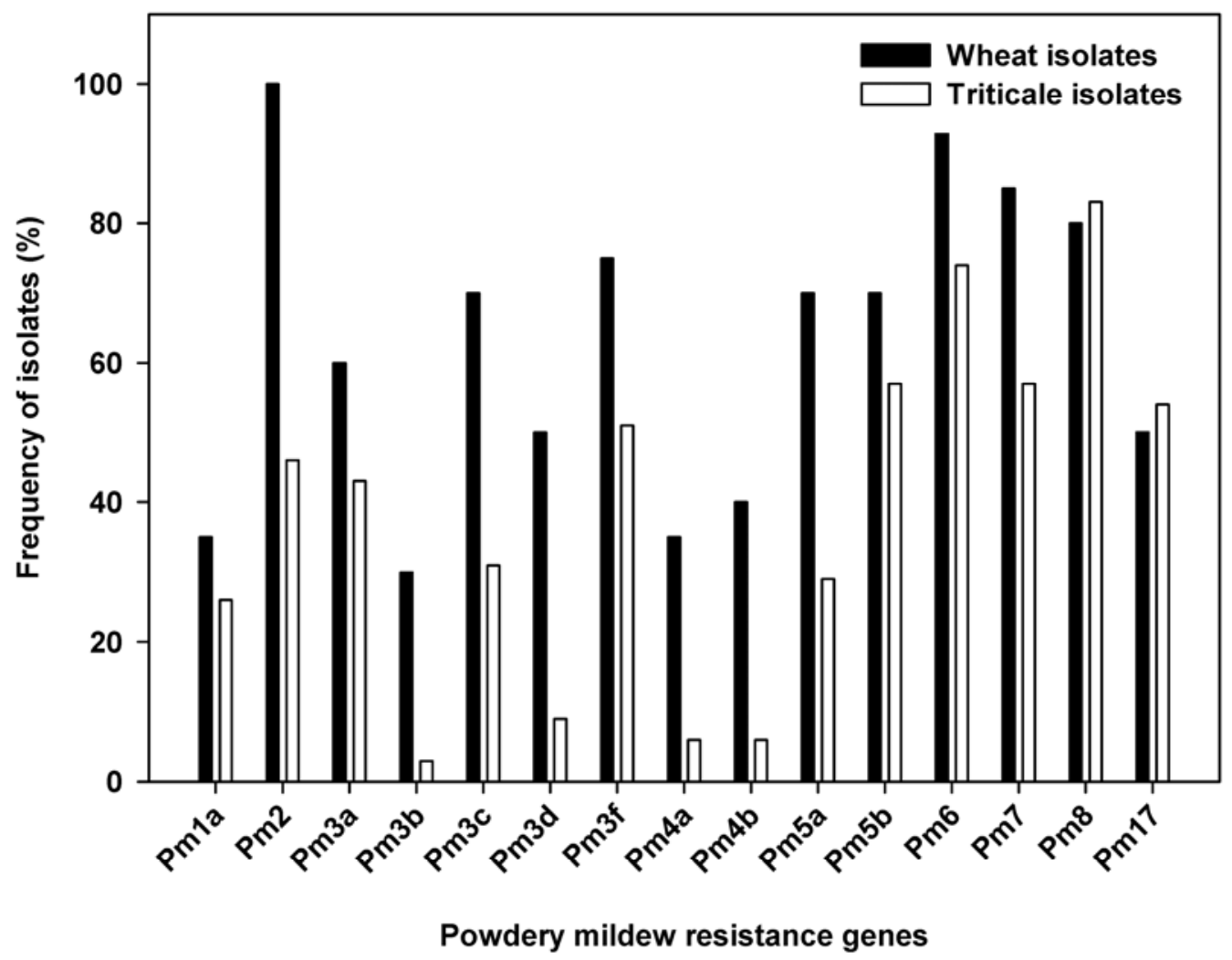

Fig. 1. Frequency of isolates (\%) virulent on each powdery mildew resistance gene $(P m)$. Data represent virulence frequencies of 20 isolates collected from wheat in Belgium, and 35 isolates collected from triticale in Belgium, France, and Poland, on wheat differential lines with known Pm genes. 
were sampled randomly from the middle row of each plot and mildew severity was assessed on the upper four leaves on a six-point scale developed by CIMMYT $(2,53)$, reflecting the percentage of leaf area covered by mildew. In some cases, flag leaves had not developed at the time of the first assessment; therefore, the score for the flag leaf at this time was set to zero, according to Yu et al. (53).

Disease severity was expressed as a disease index (DI) (i.e., the mean mildew severity on the leaves scored for a plot, expressed as a percentage of the maximum possible mean score) (53). An area under the disease progress curve (AUDPC) was calculated based on the formula of Bjarko and Line (6). SAS software (SAS Inc.) was used to compute analysis of variances (ANOVAs) followed by Tukey's multiple range comparison test, and differences at $P \leq$ 0.05 were considered statistically significant.

\section{Results}

Characterization of the triticale powdery mildew population. Infection types of isolates collected from wheat and triticale were determined on 15 wheat differential lines with known $P m$ genes (Table 1), and virulence frequencies are presented in Figure 1. Virulence to all tested $\mathrm{Pm}$ genes was identified in the powdery mildew populations collected from both wheat and triticale, although large differences in frequencies were detected. Consistently, virulence frequencies of isolates from triticale were lower than those of isolates from wheat, except for the virulence frequencies on $P m 8$ and Pm17. For the isolates collected from wheat, virulence frequencies higher than $50 \%$ were recorded on $P m 2, P m 3 a$, Pm3c, Pm3f, Pm5a,Pm5b, Pm6, Pm7, and Pm8. On the other hand, virulence frequencies higher than $50 \%$ were detected on the genes Pm3f, Pm5b, Pm6, Pm7, Pm8, and Pm17 for the isolates collected from triticale. The virulence frequencies of the isolates collected from triticale among different sampling regions (Belgium, France, and Poland) and collected in different years (2009 and 2010) were similar (data not shown).

Virulence complexity (i.e., the number of differential lines on which an isolate was virulent) in powdery mildew isolates collected from wheat and triticale is presented in Figure 2. Isolates collected from wheat and triticale carried from 4 to 13 and 0 to 11 $A V R$ genes, respectively. In general, isolates collected from wheat were more complex than isolates collected from triticale, because $65 \%$ of the wheat isolates carried 10 or more $A V R$ genes, whereas this was true for only $14 \%$ of triticale isolates. As for the virulence frequencies, the virulence complexity of the isolates collected from triticale among different sampling regions (Belgium, France, and Poland) and collected in different years (2009 and 2010) was simi$\operatorname{lar}(P \geq 0.22)$.

None of the 20 isolates collected from wheat were pathogenic on the triticale cultivars. On the other hand, all 35 isolates collected from triticale were broadly virulent on triticale, resulting in virulence frequencies higher than 50\%, except for 'Grenado', which was completely resistant, and 'Cultivo', which was only susceptible to a subset of isolates collected in Poland (Table 4).

Identification of $\mathbf{P m}$ genes in triticale by gene postulation. The disease response patterns of the wheat $P m$ differential lines after inoculation with the standard set of isolates collected from triticale are presented in Table 3. This set of isolates was used to postulate $R$ genes in triticale cultivars, and results are presented in Table 4. Four cultivars (Lamberto, 'Krakowiak', 'Grandval', and 'Tribeca') were intermediate to susceptible to all isolates, and it can be concluded that they possess none of the $R$ genes listed in Table 1. Grenado was resistant to all isolates; hence, no $R$ genes could be postulated for this cultivar. By comparing the infection types displayed on the wheat differential lines with those on the triticale cultivars after infection with the set of isolates, none of the tested $R$ genes were postulated in 'Moderato', 'Maximal', 'Borodine', 'Joyce', 'Talentro', 'Agostino', and 'Amarillo'. The presence of $R$ gene $P m 8$ was postulated in 'Ragtac', Cultivo, and 'Partout'. Additionally, the presence of $R$ gene $P m 7$ was also postulated in Cultivo.
Identification of $\mathbf{P m}$ genes in triticale by molecular markers. For the presence of the 1RS translocation in the triticale genotypes, results indicated that the diagnostic bands of 400, 600, and $800 \mathrm{bp}$ in length were amplified in all triticale genotypes, as well as in the positive controls Kavkaz and Amigo.

The IAG95 marker was used to distinguish the 1BL.1RS translocation from 1AL.1RS. Contrary to the results of the gene postulation, the presence of $P m 8$ (1BL.1RS translocation) was only detected in the positive control Kavkaz and not in any of the triticale genotypes. On the other hand, the presence of Pm17 (1AL.1RS translocation) was detected in 13 triticale genotypes (Table 4). The presence of $\mathrm{Pm} 17$ was not detected in Moderato and Grenado.

Although different PCR conditions were tested, the presence of Pm $3 a$ could not be detected because many nonspecific bands were obtained in the positive control. The presence of the $P m 3 b, P m 3 c$, and $P m 3 d$ alleles was not detected on any of the tested triticale genotypes. On the other hand, the Pm3f allele was found to be present in Moderato, Grenado, Borodine, Joyce, Talentro, and Amarillo (Table 4). These results are not in agreement with those from the gene postulation.

Evaluation of adult plant resistance in triticale. Natural powdery mildew infection was observed in both years, and the susceptible check Lamberto was heavily covered with powdery mildew. Consistently for all cultivars, a higher disease severity was observed in the growing season of 2010-11. These results indicate that powdery mildew infections are clearly influenced by the yearly weather conditions. Spring 2011 was sunnier and drier than ever before in Belgium, with a monthly average of $22.5 \mathrm{~mm}$ of precipitation in May 2011 compared with $66.6 \mathrm{~mm}$ in May 2010.


Fig. 2. Virulence complexity (number of differential lines on which an isolate was virulent) in powdery mildew isolates collected from wheat $(n=20)$ in Belgium and triticale $(n=35)$ in Belgium, France, and Poland. 
The DI at the last evaluation date (DIfin) and the AUDPC were highly correlated, with a correlation coefficient of $0.96(P<$ 0.0001 ), both when results of the two seasons were pooled and for the seasons separately. Therefore, below, only the parameter AUDPC will be discussed in detail, and results are shown in Figure 3. Moreover, this indicates that a single scoring at an appropriate time might be sufficient in practical breeding. In the ANOVA of DIfin and AUDPC, highly significant differences were found for triticale genotypes and crop seasons (Table 5). The cultivar-season interaction was also significant but its effect on variation was much smaller than the genotypic differences.

Krakowiak and Maximal were highly susceptible to powdery mildew, resulting in significantly higher AUDPC values $(>800)$ than the other genotypes (Fig. 3). However, these AUDPC values were significantly lower than those of the susceptible check Lamberto. Ragtac was classified as a moderately susceptible genotype, resulting in a mean AUDPC value of 500. Six genotypes, including Joyce, Borodine, Grandval, Talentro, Tribeca, and Moderato, had a mean AUDPC value between 100 and 303 and, therefore, were classified as moderately resistant cultivars. Despite the high disease pressure, five highly resistant cultivars were identified, resulting in extremely low AUDPC values $(<40)$. Those cultivars were Grenado, Cultivo, Amarillo, Partout, and Agostino.

\section{Discussion}

The main goal of this study was to identify the presence of powdery mildew resistance in commercial triticale cultivars. Virulence was identified for all the $R$ genes evaluated in the present study

Table 4. Infection types and virulence frequencies of triticale cultivars with unknown resistance genes against a standard set of Blumeria graminis isolates collected from triticale

\begin{tabular}{|c|c|c|c|c|c|c|c|c|c|c|c|c|c|c|c|c|c|c|}
\hline \multirow[b]{2}{*}{ Cultivar } & \multirow[b]{2}{*}{$\operatorname{Vir}(\%)^{b}$} & \multicolumn{15}{|c|}{ Standard set of isolates collected from triticale ${ }^{a}$} & \multirow[b]{2}{*}{ Postulated $^{\mathrm{c}}$} & \multirow[b]{2}{*}{$\mathbf{P C R}^{\mathbf{d}}$} \\
\hline & & A27 & A37 & C6 & $\mathbf{C 1 0}$ & $\mathbf{C 3}$ & B14 & B8 & A28 & C9 & B9 & $\mathbf{A 2 1}$ & A24 & $\mathrm{C2}$ & C8 & $\mathbf{A 2 2}$ & & \\
\hline Lamberto & 91.4 & $\mathrm{~S}$ & I & $\mathrm{S}$ & $\mathrm{S}$ & $\mathrm{S}$ & $\mathrm{S}$ & I & $\mathrm{S}$ & $\mathrm{S}$ & $\mathrm{S}$ & $\mathrm{S}$ & I & $\mathrm{S}$ & $\mathrm{S}$ & $\mathrm{S}$ & None & Pm17 \\
\hline Krakowiak & 100.0 & $\mathrm{~S}$ & $\mathrm{~S}$ & $\mathrm{~S}$ & $\mathrm{~S}$ & $\mathrm{~S}$ & $\mathrm{~S}$ & S & $\mathrm{S}$ & $S$ & $\mathrm{~S}$ & $\mathrm{~S}$ & $\mathrm{~S}$ & $\mathrm{~S}$ & $S$ & $\mathrm{~S}$ & None & Pm17 \\
\hline Moderato & 54.3 & $\mathrm{~S}$ & $\mathrm{R}$ & I & $\mathrm{S}$ & $\mathrm{S}$ & $\mathrm{R}$ & $\mathrm{R}$ & $\mathrm{S}$ & $S$ & $\mathrm{R}$ & $\mathrm{R}$ & $\mathrm{R}$ & $\mathrm{R}$ & $S$ & $\mathrm{~S}$ & None & $P m 3 f$ \\
\hline Grenado & 0.0 & $\mathrm{R}$ & $\mathrm{R}$ & $\mathrm{R}$ & $\mathrm{R}$ & $\mathrm{R}$ & $\mathrm{R}$ & $\mathrm{R}$ & $\mathrm{R}$ & $\mathrm{R}$ & $\mathrm{R}$ & $\mathrm{R}$ & $\mathrm{R}$ & $\mathrm{R}$ & $\mathrm{R}$ & $\mathrm{R}$ & Unknown & $P m 3 f$ \\
\hline Maximal & 97.1 & $\mathrm{~S}$ & $\mathrm{R}$ & $\mathrm{S}$ & $\mathrm{S}$ & $\mathrm{S}$ & $\mathrm{S}$ & $\mathrm{S}$ & $\mathrm{S}$ & $S$ & $\mathrm{~S}$ & $\mathrm{~S}$ & $\mathrm{~S}$ & $S$ & $S$ & $\mathrm{~S}$ & None & Pm17 \\
\hline Grandval & 97.1 & $\mathrm{~S}$ & $\mathrm{~S}$ & $\mathrm{~S}$ & $\mathrm{~S}$ & $\mathrm{~S}$ & $\mathrm{~S}$ & $\mathrm{~S}$ & $\mathrm{~S}$ & $S$ & $\mathrm{~S}$ & $\mathrm{~S}$ & $\mathrm{~S}$ & $\mathrm{~S}$ & $S$ & $\mathrm{~S}$ & None & Pm17 \\
\hline Borodine & 77.1 & $\mathrm{~S}$ & $\mathrm{R}$ & $\mathrm{S}$ & $\mathrm{R}$ & $\mathrm{R}$ & $\mathrm{S}$ & $\mathrm{R}$ & $S$ & $S$ & $\mathrm{~S}$ & $S$ & $\mathrm{R}$ & I & $S$ & $\mathrm{~S}$ & None & Pm $3 f, P m 17$ \\
\hline Ragtac & 85.7 & $\mathrm{~S}$ & $\mathrm{~S}$ & $\mathrm{~S}$ & $\mathrm{~S}$ & $\mathrm{R}$ & $\mathrm{S}$ & $\mathrm{R}$ & $\mathrm{S}$ & $S$ & $\mathrm{~S}$ & $\mathrm{~S}$ & $\mathrm{~S}$ & $\mathrm{~S}$ & $S$ & I & $\operatorname{Pm} 8$ & Pm17 \\
\hline Joyce & 91.4 & S & S & $\mathrm{S}$ & S & $\mathrm{R}$ & S & $\mathrm{R}$ & S & S & $\mathrm{S}$ & S & S & S & S & S & None & Pm3f, Pm17 \\
\hline Tribeca & 91.4 & $\mathrm{~S}$ & $\mathrm{~S}$ & $\mathrm{~S}$ & I & $\mathrm{S}$ & $\mathrm{S}$ & $\mathrm{S}$ & $\mathrm{S}$ & $S$ & $\mathrm{~S}$ & $\mathrm{~S}$ & $\mathrm{~S}$ & $\mathrm{~S}$ & I & $\mathrm{S}$ & None & Pm17 \\
\hline Talentro & 88.6 & $\mathrm{~S}$ & $\mathrm{~S}$ & $\mathrm{~S}$ & $\mathrm{~S}$ & $\mathrm{R}$ & $\mathrm{S}$ & $\mathrm{R}$ & $\mathrm{S}$ & $\mathrm{S}$ & $\mathrm{S}$ & $\mathrm{S}$ & $\mathrm{S}$ & $\mathrm{S}$ & $\mathrm{S}$ & $\mathrm{S}$ & None & Pm3f, Pm17 \\
\hline Cultivo & 5.7 & $\mathrm{R}$ & $\mathrm{R}$ & $\mathrm{R}$ & $S$ & $\mathrm{R}$ & $\mathrm{R}$ & $\mathrm{R}$ & $\mathrm{R}$ & $\mathrm{R}$ & $\mathrm{R}$ & $\mathrm{R}$ & $\mathrm{R}$ & $\mathrm{R}$ & $S$ & $\mathrm{R}$ & $\operatorname{Pm} 7, \operatorname{Pm} 8$ & Pm17 \\
\hline Agostino & 88.6 & $\mathrm{~S}$ & I & $\mathrm{S}$ & $\mathrm{S}$ & $\mathrm{R}$ & $\mathrm{S}$ & $\mathrm{R}$ & $\mathrm{S}$ & $\mathrm{S}$ & $\mathrm{S}$ & $\mathrm{S}$ & I & $\mathrm{S}$ & $\mathrm{S}$ & $\mathrm{S}$ & None & Pm17 \\
\hline Partout & 57.1 & $\mathrm{R}$ & $\mathrm{R}$ & $\mathrm{S}$ & $\mathrm{S}$ & $\mathrm{R}$ & $\mathrm{S}$ & $\mathrm{S}$ & $\mathrm{R}$ & $\mathrm{S}$ & $\mathrm{S}$ & $\mathrm{S}$ & I & $\mathrm{S}$ & $\mathrm{R}$ & $\mathrm{R}$ & Pm8 & Pm17 \\
\hline Amarillo & 60.0 & S & $\mathrm{R}$ & $\mathrm{R}$ & $\mathrm{R}$ & $\mathrm{S}$ & I & $\mathrm{S}$ & S & $\mathrm{R}$ & $\mathrm{S}$ & S & S & $S$ & I & S & none & Pm3f, Pm17 \\
\hline
\end{tabular}

${ }^{a} \mathrm{R}$, resistant; I, intermediate; $\mathrm{S}$, susceptible.

${ }^{\mathrm{b}}$ Virulence frequency. Data represent the percentage of 35 isolates, collected from triticale in Belgium, France, and Poland, virulent on the respective triticale cultivars.

${ }^{c}$ Postulated $P m$ genes; Pm genes not tested in the wheat differential set could not be detected.

${ }^{\mathrm{d}}$ Polymerase chain reaction (PCR) detection of Pm3 alleles and of the 1AL.1RS (Pm17) and 1BL.1RS (Pm8) wheat-rye translocations.



Fig. 3. Boxplot indicating median, interquartile, and entire range of area under the disease progress curve (AUDPC) values from powdery mildew infection on 15 triticale genotypes. Stars refer to outlying data points. Results represent pooled data from growing seasons 2009-10 and 2010-11. Means of AUDPC values of cultivars with a different letter differ significantly according to Tukey $(P<0.05)$. 
from the powdery mildew collections from both wheat and triticale. These results reveal that none of the tested $R$ genes still provides effective powdery mildew resistance. For the isolates collected from wheat, virulence frequencies higher than $50 \%$ were recorded on Pm2, Pm3a, Pm3c, Pm3f, Pm5a, Pm5b, Pm6, Pm7, and $P m 8$. Average to high virulence frequencies against these genes were already reported a decade ago by Hsam and Zeller (16) in Europe and, more recently, by Parks et al. (37) in the eastern United States and by Bayles and Borrows (3) in the United Kingdom. For the isolates collected from triticale, virulence frequencies higher than $50 \%$ were detected on the genes $P m 3 f$, Pm5b, Pm6, Pm7, Pm8, and Pm17. Strikingly, these include three genes (e.g., $P m 7, P m 8$, and $P m 17$ ) which originate from rye (16) (Table 1). Moreover, Walker et al. (49) also detected high infection rates of wheat and triticale isolates on wheat 'Clément', which carries the $P m 8$ gene.

Analysis of the virulence complexity showed that isolates collected from wheat were more complex than isolates collected from triticale. Previous research showed that powdery mildew on triticale has recently emerged through a host range expansion of powdery mildew on wheat $(48,49)$; therefore, it might be expected that both populations would have similar virulence complexities. However, breeding for powdery mildew resistance has never been a goal in triticale whereas, during the last decade, wheat hosts carrying different $P m$ genes were selected. In this way, the powdery mildew population on triticale could have been subjected to lower selection pressure than the powdery mildew population on wheat, resulting in a lower virulence complexity. Additionally, the genetic diversity of the powdery mildew population on wheat was found to be higher than that of the population on triticale (48). This is probably because the powdery mildew population on triticale passed through a bottleneck of population size when it diverged from the wheat powdery mildew population.

The second objective was to identify the presence of $\mathrm{Pm}$ genes that condition powdery mildew resistance in commercial triticale cultivars. Because the availability of molecular markers for PCR detection of $P m$ genes is limited, we also postulated $R$ genes by multipathotype seedling tests, based on the gene-for-gene relationship (14). However, the results of the gene postulation were not in agreement with the results of the PCR detection of Pm genes. The $R$ gene $P m 8$ was postulated in some of the tested triticale cultivars, while this was not confirmed by the use of the IAG95 molecular marker. Notwithstanding, the use of the IAG95 marker did reveal the presence of $R$ gene $P m 17$ in most of the tested triticale cultivars. Lillemo et al. (24) found similar results by combining gene postulation with molecular data but there are several possible explanations for the apparent contradiction found in this study. Because the triticale isolates characterized using our differential set each presented more than one AVR factor, precise $R$ gene combinations could not always be inferred. Second, gene postulation can be complicated by interactions between $R$ genes. This was recently found for the rye-derived powdery mildew $R$ gene $P m 8$ in wheat, which is suppressed by translated alleles at the Pm3 locus (29). Additionally, it is known that genes introgressed from species of lower ploidy (like the rye-derived powdery mildew $R$ genes) often confer lower levels of resistance than in the original host, as shown by The and Baker (46), McIntosh and Dyck (28), and Nelson et al. (34). In particular, it is possible that, in the hybrid crop triticale, rye $R$ genes are not expressed properly in the presence of the wheat genome and vice versa. Another line of argument is that the expression of $R$ genes is influenced by the plant stage (16). In particular, $R$ genes are not always expressed at the seedling stage, whereas 2-week-old seedlings were evaluated for the gene postulation in this study. As early as 1984, Bennett (4) mentioned that Amigo carrying Pm17 was highly resistant at the adult plant stage, although severe infection was observed at the seedling stage. Finally, because nothing is known about the genetic distance between the IAG95 molecular marker and the $P m 8 / P m 17$ gene for resistance in triticale, recombination between the marker and the gene might also explain the discordance in the results.
The presence of the rye-derived $R$ gene $P m 17$ in most of the current triticale cultivars is highly likely, because this gene might have been present in one of the ancestors of the rye parent. Pm17 is located on the same chromosome arm as $R$ gene $P m 8$ but translocated to wheat chromosome 1AL instead of 1BL (16). Transferring gene Pm17 in Amigo from a T1AL.1RS to a T1BL.1RS translocation in line 'Helami-105' and subsequent crosses with $\operatorname{Pm} 8$ cultivars have shown that the two genes are allelic (15). Recently, higher infestations of powdery mildew on wheat cultivars carrying Pm17 were recorded in both Europe (21) and the United States (10). This might be related to the resistance breakdown of triticale cultivars, also carrying Pm17. Only the Pm3f allele was found to be present in some of the triticale cultivars. $P m 3 f$ was considered a rare allele, not known to have been used frequently in continental European wheat breeding (47). However, recently, it was detected in spring wheat cultivars in Estonia (38) and Scandinavia (24). Obviously, other known or unknown $R$ genes which were not evaluated in this study could be present in triticale. The finding that the triticale cultivars in this study, although from different European breeding companies, carry almost the same powdery mildew $R$ genes underscores the narrow genetic background of triticale in relation to powdery mildew resistance. Moreover, it is known that triticale germplasm is widely shared among breeding centers from around the world (23). This widespread use of genetically uniform varieties provides an ideal genetic environment for disease epidemics (45).

The abovementioned results highlight the rapid evolutionary potential of $B$. graminis and, consequently, the need to improve the durability of race-specific powdery mildew $R$ genes. Given the large number of virulences in present-day triticale powdery mildew populations, control via pyramiding $R$ genes (i.e., combining several different $R$ genes in the same plant) would likely not be effective in the long term. McDonald and Linde (27) suggest that, for the $B$. graminis pathosystem, major $R$ genes should be managed aggressively, including development of cultivar mixtures and multilines that can be used in combination with regional and temporal deployment strategies. Multilines have been proven effective in disease reduction in small grain crops (33) but a limiting factor is the long development time needed to backcross different $R$ genes into a common genetic background. Moreover, McDonald and Linde (27) suggest that breeding effort should concentrate on quantitative resistance, if available, which might need to be renewed regularly to stay ahead of the pathogen. Examples of durable quantitative resistance include the winter cultivar Knox (42) and the derived cultivar Massey (25), which have provided effective resistance against powdery mildew in the southeastern United States for half a century.

For the field experiment, the variation in resistance levels between the different cultivars was consistent over the 2 years,

Table 5. Analysis of variance of final disease index (DIfin) and area under the disease progress curve (AUDPC) in 15 triticale genotypes, tested in the 2009-10 and 2010-11 crop seasons

\begin{tabular}{lccc}
\hline Parameter, source $^{\mathbf{a}}$ & $\mathbf{d f}^{\mathbf{b}}$ & Mean of squares & $\boldsymbol{F}$ value $^{\mathbf{c}}$ \\
\hline DIfin & & & \\
Cultivar (S) & 14 & $4,388.8$ & $93.1^{* * *}$ \\
Block & 3 & 38.2 & $0.8 \mathrm{~ns}$ \\
Season (S) & 1 & $2,144.3$ & $45.5^{* * *}$ \\
C $\times$ S & 14 & 134.15 & $2.8^{*}$ \\
Error & 87 & 47.2 & $\ldots$ \\
AUDPC & & & \\
C & 14 & $1,071,243.5$ & $101.3^{* * *}$ \\
Block & 3 & $24,300.08$ & $2.3 \mathrm{~ns}$ \\
S & 1 & $201,662.6$ & $19.1 * * *$ \\
C $\times$ S & 14 & $30,214.6$ & $2.9 *$ \\
Error & 87 & $10,574.1$ & $\ldots$ \\
\hline
\end{tabular}

\footnotetext{
a Source of variation.

${ }^{\mathrm{b}}$ Degrees of freedom.

c $P$ values were estimated: ns indicates $P>0.01, *$ indicates $P<0.01$, and
} *** indicates $P<0.0001$ 
although a higher disease severity was observed in 2010-11. This underscores the influence of yearly weather on powdery mildew infections, which was also observed by Miedaner and Flath (30). The results revealed that the cultivars varied significantly in adultplant resistance to powdery mildew. Despite the high disease pressure, cultivars highly resistant at the adult-plant growth stages were identified in the field. Those cultivars were Grenado, Cultivo, Amarillo, Partout, and Agostino. Generally, adult-plant resistance to powdery mildew is detected in cultivars that either have no identified major $R$ genes or whose major gene resistance has been overcome (4). The latter was true for Amarillo, Partout, and Agostino. This was also observed in Chinese wheat cultivars $(50,53)$. Yu et al. (53) referred to this resistance of varieties, susceptible as seedlings but relatively resistant in the field, as effective, race-specific adult-plant resistance rather than partial resistance. Because Grenado also showed effective race-specific resistance, this cultivar could be of high value for breeding for durable resistance to powdery mildew in triticale.

Altogether, this study reveals valuable information on the presence of powdery mildew resistance in commercial triticale cultivars, which can be used in breeding programs for durable powdery mildew resistance in triticale. However, more genetic analysis of race-specific and adult plant resistance in different triticale genotypes is needed for their efficient use in breeding for powdery mildew resistance. Moreover, this study highlights the narrow genetic base of triticale in relation to powdery mildew resistance. This underscores the need to broaden the base of powdery mildew resistance in triticale through introgression and deployment of new sources of mildew resistance, including quantitative resistance. We expect that powdery mildew will become a devastating disease in triticale if adequate attention is not paid to efficient powdery mildew resistance breeding.

\section{Acknowledgments}

This project was funded by a grant from the University College Ghent (Ghent University Association). We thank J. Brown from John Innes Centre (Norwich, UK) for his expertise and training and for sending the seed of the wheat differentials, all of the generous collaborators who helped us collect $B$. graminis by sending us samples, A. Bouguennec from INRA (Clermont-Ferrand, France) for collecting the French samples, and P. Czembor and O. Domeradzka from IHAR (Radzikow, Poland) for collecting the Polish samples.

\section{Literature Cited}

1. Ammar, K., Mergoum, M., and Rajaram, S. 2004. The history and evolution of triticale. In: Triticale Improvement and Production. M. Mergoum and H. Gomez-Maxpherson, eds. FAO Plant Prod. Prot. Pap. 179:1-9.

2. Anonymous. 1981. Forecasting methods for diseases and insect pests of main crops. Pages 158-161 in: General Station of Diseases and Insect Pests Forecasting of Agricultural Ministry of China. Agricultural Publishing House, Beijing.

3. Bayles, R. A., and Borrows, R. E. 2010. Mildew of wheat. UK cereal pathogen virulence survey 2010. Annual Report, HGCA, UK. http://www.hgca. com/document.aspx?fn=load\&media_id=7242\&publicationId $=56$

4. Bennett, F. G. A. 1984. Resistance to powdery mildew in wheat: a review of its use in agriculture and breeding programmes. Plant Pathol. 33:279-300.

5. Bent, A. F., and Mackey D. 2007. Elicitors, effectors and $R$ genes: the new paradigm and a lifetime supply of questions. Annu. Rev. Phytopathol. 45:399-436.

6. Bjarko, M. E., and Line, R. F. 1988. Heritability and number of genes controlling leaf rust resistance in four cultivars of wheat. Phytopathology 78:457-461.

7. Brown, J. K. M., and Wolfe, M. S. 1990. Structure and evolution of a population of Erysiphe graminis f. sp. hordei. Plant Pathol. 39:376-390.

8. Conner, R. L., Kuzyk, A. D., and Su, H. 2003. Impact of powdery mildew on the yield of soft white spring wheat cultivars. Can. J. Plant Sci. 83:725728.

9. Cowger, C., Miranda, L., Griffey, C., Hall, M., Murphy, J. P., and Maxwell, J. 2012. Wheat powdery mildew. Pages 84-119 in: Disease Resistance in Wheat. I. Sharma, ed. CAB International, Wallingford, United Kingdom.

10. Cowger, C., Parks, R., and Marshall, D. 2009. Appearance of powdery mildew of wheat caused by Blumeria graminis f. sp. tritici on Pm17-bearing cultivars in North Carolina. Plant Dis. 93:1219-1219.

11. Dodds, P. N., and Rathjen, J. P. 2010. Plant Immunity: towards an integrated view of plant-pathogen interactions. Nat. Rev. Genet. 11:539-548.

12. Everts, K. L., Leath, S., and Finney, P. L. 2001. Impact of powdery mildew and leaf rust on milling and baking quality of soft red winter wheat. Plant Dis. 85:423-429.
13. FAOSTAT. http://faostat.fao.org/site/567/DesktopDefault.aspx?PageID=567

14. Flor, H. H. 1971. Current status of the gene-for-gene concept. Annu. Rev. Phytopathol. 9:275-296.

15. Hsam, S. L. K., and Zeller, F. J. 1997. Evidence of allelism between genes $P m 8$ and $P m 17$ and chromosomal location of powdery mildew and leaf rust resistance genes in the common wheat cultivar 'Amigo'. Plant Breed. 116:119-122.

16. Hsam, S. L. K., and Zeller, F. J. 2002. Breeding for powdery mildew resistance in common wheat (Triticum aestivum L.). Pages 219-238 in: The Powdery Mildews. A Comprehensive Treatise. R. R. Bélanger, W. R. Bushnell, A. J. Dik, and T. L. W. Carver, eds. American Phytopathological Society, St. Paul, MN.

17. Hysing, S.-C., Merker, A., Liljeroth, E., Koebner, R. M. D., Zeller, F. J., and Hsam, S. L. K. 2007. Powdery mildew resistance in 155 Nordic bread wheat cultivars and landraces. Hereditas 144:102-119.

18. Imani, Y., Ouassou, A., and Griffey, C. A. 2002. Virulence of Blumeria graminis f. sp. tritici populations in Morocco. Plant Dis. 86:383-388.

19. Jones, J. D. G., and Dangl, J. L. 2006. The plant immune system. Nature 444:323-329.

20. Koebner, R. M. D. 1995. Generation of PCR-based markers for the detection of rye chromatin in a wheat background. Theor. Appl. Genet. 90:740745 .

21. Komáromi, J., and Vida, G. 2009. Effectiveness of designated major powdery mildew resistance genes in various wheat genotypes. Cereal Res. Commun. 37:213-216.

22. Kou, Y., and Wang, S. 2010. Broad-spectrum and durability: understanding of quantitative disease resistance. Curr. Opin. Plant Biol. 13:181-185.

23. Kuleung, C., Baenziger, P. S., Kachman, S. D., and Dweikat, I. 2006. Evaluating the genetic diversity of triticale with wheat and rye SSR markers. Crop Sci. 46:1692-1700.

24. Lillemo, M., Skinnes, H., and Brown, J. K. M. 2010. Race specific resistance to powdery mildew in Scandinavian wheat cultivars, breeding lines and introduced genotypes with partial resistance. Plant Breed. 129:297-303.

25. Liu, S. X., Griffey, C. A., and Maroof, M. A. S. 2001. Identification of molecular markers associated with adult plant resistance to powdery mildew in common wheat cultivar Massey. Crop Sci. 41:1268-1275.

26. Marchal, E. 1902. De la spécialisation du parasitisme chez l'Eysiphe graminis. C. R. Acad. Sci. Paris 135:210-212.

27. McDonald, B. A., and Linde, C. 2002. The population genetics of plant pathogens and breeding strategies for durable resistance. Euphytica 124:163-180

28. McIntosh, R. A., and Dyck, P. L. 1975. Cytogenetical studies in wheat VII. Gene Lr23 for reaction to Puccinia recondita in Gabo and related cultivars. Aust. J. Biol. Sci. 28:201-211.

29. McIntosh, R. A., Zhang, P., Cowger, C., Parks, R., Lagudah, E. S., and Hoxha, S. 2011. Rye-derived powdery mildew resistance gene Pm8 in wheat is suppressed by the Pm3 locus. Theor. Appl. Genet. 123:359-367.

30. Miedaner, T., and Flath, K. 2007. Effectiveness and environmental stability of quantitative powdery mildew (Blumeria graminis) resistance among winter wheat cultivars. Plant Breed. 126:553-558.

31. Mohler, V., Hsam, S. L. K., Zeller, F. J., and Wenzel, G. 2001. An STS marker distinguishing the rye-derived powdery mildew resistance alleles at the Pm8/Pm17 locus of common wheat. Plant Breed. 120:448-450.

32. Moseman, J. G., Macer, R. C. F., and Greeley, L. W. 1965. Genetic studies with cultures of Erysiphe graminis f. sp. hordei virulent on Hordeum spontaneum. Trans. Br. Mycol. Soc. 48:479-489.

33. Mundt, C. C. 2002. Use of multiline cultivars and cultivar mixtures for disease management. Annu. Rev. Phytopathol. 40:381-410.

34. Nelson, J. C., Singh, R. P., Autrique, J. E., and Sorrells, M. E. 1997. Mapping genes conferring and suppressing leaf rust resistance in wheat. Crop Sci. 37:1928-1935.

35. Oettler, G. 2005. The fortune of a botanical curiosity-triticale: past, present and future. J. Agric. Sci. 143:329-346.

36. Oku, T., Yamashita, S., Doi, Y., and Nishihara, N. 1985. Host range and formae speciales of cocksfoot powdery mildew (Erysiphe graminis DC) found in Japan. Ann. Phytopathol. Soc. Jpn. 51:613-615.

37. Parks, R., Carbone, I., Murphy, J. P., Marshall, D., and Cowger, C. 2008. Virulence structure of the eastern U.S. wheat powdery mildew population. Plant Dis. 92:1074-1082.

38. Peusha, H., Enno, T., Jakobson, I., Tsõmbalova, J., Ingver, A., and Järve, K 2008. Powdery mildew resistance of Nordic spring wheat cultivars grown in Estonia. Acta Agric. Scand. 58:289-296.

39. Poland, J. A., Balint-Kurti, P. J., Wisser, R. J., Pratt, R. C., and Nelson, R. J. 2009. Shades of gray: the world of quantitative disease resistance. Trends Plant Sci. 14:21-29.

40. Salmon, D. F., Mergoum, M., and Gomez-Maxpherson, H. 2004. Triticale production and management. In: Triticale Improvement and Production. M. Mergoum and H. Gomez-Maxpherson, eds. FAO Plant Prod. Prot. Pap. 179:27-36

41. Schmolke, M., Mohler, V., Hartl, L., Zeller, F. J., and Hsam, S. L. K. 2012 A new powdery mildew resistance allele at the Pm4 wheat locus transferred from einkorn (Triticum monococcum). Mol. Breed. 29:449-456.

42. Shaner, G. 1973. Evaluation of slow-mildewing resistance of Knox wheat in the field. Phytopathology 63:867-872. 
43. Singrün, C., Rauch, P., Morgounov, A., Hsam, S., and Zeller, F. 2004. Identification of powdery mildew and leaf rust resistance genes in common wheat (Triticum aestivum L.). Wheat varieties from the Caucasus, Central and Inner Asia. Genet. Resour. Crop Evol. 51:355-370.

44. St. Clair, D. A. 2010. Quantitative disease resistance and quantitative resistance loci in breeding. Annu. Rev. Phytopathol. 48:247-268.

45. Stukenbrock, E. H., and McDonald, B. A. 2008. The origins of plant pathogens in agro-ecosystems. Annu. Rev. Phytopathol. 46:75-100.

46. The, T. T., and Baker, E. P. 1975. Basic studies relating to the transference of genetic characters from Triticum monococcum L. to hexaploid wheat. Aust. J. Biol. Sci. 28:189-199.

47. Tommasini, L., Yahiaoui, N., Srichumpa, P., and Keller, B. 2006. Development of functional markers specific for seven $P m 3$ resistance alleles and their validation in the bread wheat gene pool. Theor. Appl. Genet. 114:165-175.

48. Troch, V., Audenaert, K., Bekaert, B., Höfte, M., and Haesaert, G. 2012. Phylogeography and virulence structure of the powdery mildew population on its 'new' host triticale. BMC Evol. Biol. 12:76.

49. Walker, A. S., Bouguennec, A., Confais, J., Morgant, G., and Leroux, P.
2011. Evidence of host-range expansion from new powdery mildew (Blumeria graminis $)$ infections of triticale $(\times$ Triticosecale $)$ in France. Plan Pathol. 60:207-220.

50. Wang, Z. L., Li, L. H., He, Z. H., Duan, X. Y., Zhou, Y. L., Chen, X. M. Lillemo, M., Singh, R. P., Wang, H., and Xia, X. C. 2005. Seedling and adult plant resistance to powdery mildew in Chinese bread wheat cultivars and lines. Plant Dis. 89:457-463.

51. Weng, Y., Azhaguvel, P., Devkota, R. N., and Rudd, J. C. 2007. PCR-based markers for detection of different sources of 1AL.1RS and 1BL.1RS wheatrye translocations in wheat background. Plant Breed. 126:482-486.

52. Yahiaoui, N., Srichumpa, P., Dudler, R., and Keller, B. 2004. Genome analysis at different ploidy levels allow cloning of the powdery mildew resistance gene $P m 3 b$ from hexaploid wheat. Plant J. 37:528-538.

53. Yu, D. Z., Yang, X. J., Yang, L. J., Jeger, M. J., and Brown, J. K. M. 2001. Assessment of partial resistance to powdery mildew in Chinese wheat varieties. Plant Breed. 120:279-284.

54. Zadoks, J. C., Chang, T. T., and Konzak, C. F. 1974. A decimal code for the growth stage of cereals. Weed Res. 14:415-421. 